\title{
SiM
}

\section{Early Season Grazing by Cattle of Waxy Larkspur (Delphinium glaucescens) in Central Idaho}

\author{
By James A. Pfister, Daniel Cook, Dale R. Gardner, and Sarah D. Baker
}

\section{On the Ground}

- Toxic larkspurs (Delphinium spp.) in western North America are abundant native plants on foothill and mountain rangelands.

- Previous analysis for toxic alkaloids in waxy larkspur indicated that this plant was highly toxic. However, no information on cattle grazing of waxy larkspur was available.

- We conducted a small grazing study in spring 2012 near Challis, Idaho, and found that cattle consumed sufficient quantities of waxy larkspur to become poisoned. The risk of death losses by cattle is particularly high because of the very high concentrations of alkaloids in young waxy larkspur plants.

Keywords: Delphinium, larkspur, cattle, grazing, alkaloids, poisonous plants.

Rangelands 35(4):2-5

doi: 10.2111/RANGELANDS-D-13-00014.1

(c) 2013 The Society for Range Management

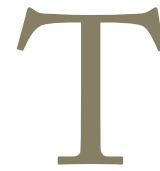

oxic larkspurs (Delphinium spp.) in western North America are abundant native plants on foothill and mountain rangelands, typically with showy blue flowers. Larkspurs are often divided into three classes depending on the plant height: tall, low, and plains larkspur. Tall larkspurs include four species: subalpine larkspur (Delphinium barbeyi), duncecap larkspur (Delphinium occidentale), sierra larkspur (Delphinium glaucum), and waxy larkspur (Delphinium glaucescens, sometimes referred to as smooth larkspur). These long-lived perennial plants typically begin to grow in spring under snow banks and continue rapid spring or summer growth when snow banks recede. Tall larkspurs take about 50 to 60 days to reach mature height from the onset of growth, and they begin to flower when plants have reached about $75 \%$ of their mature height. After flowering, seed pods begin to form from mature flowers. These pods are very palatable to cattle and are often avidly consumed in late summer. After the pods mature, they split open and mature seeds are dispersed. After the pods break open, the plants begin to rapidly senesce.

Subalpine and duncecap larkspur are the dominant tall larkspur species across much of the western United States, and most of the research work in the Poisonous Plant Research Laboratory (PPRL) has focused on these two tall larkspur species. ${ }^{1}$ Sierra larkspur grows primarily in the mountains of California, Oregon, and the Canadian Rockies. Waxy larkspur occurs primarily in the mountains of central Idaho and southwestern Montana near the Continental Divide (Fig. 1). The distribution of waxy larkspur overlaps that of duncecap larkspur in Idaho and Montana, and there has been some uncertainty about identification of these two species. Currently

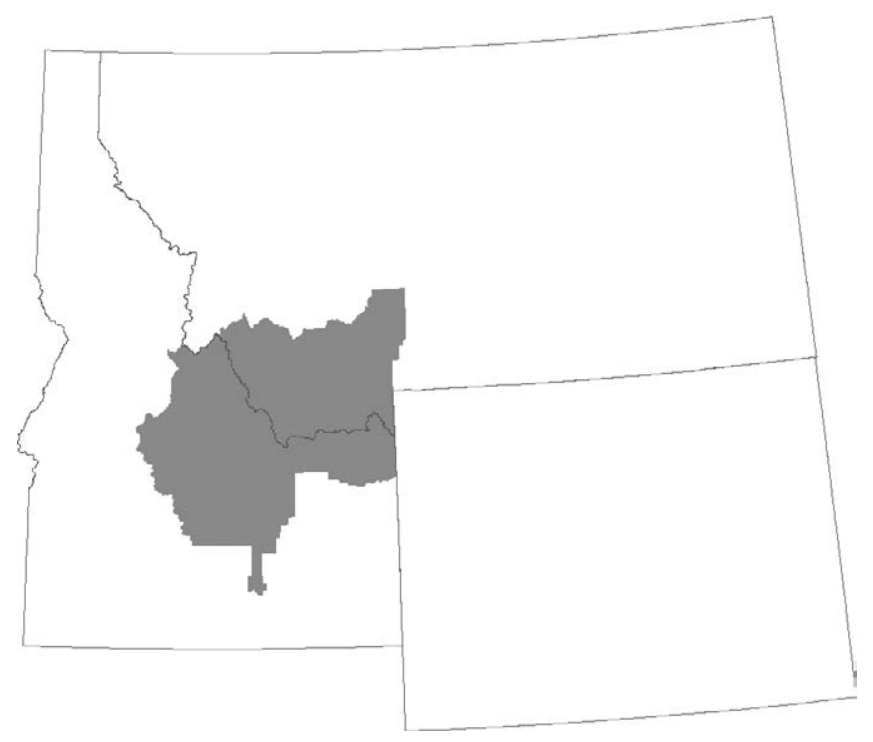

Figure 1. Distribution of waxy larkspur (Delphinium glaucescens) in Idaho and Montana. 
identification of these two species, particularly in areas where they overlap, is based on both morphological features used in traditional plant taxonomy and the chemical fingerprint of the alkaloid chemicals contained in the two species.

Tall larkspurs typically contain numerous toxic alkaloids, which often cause substantial death losses when grazed by cattle. The alkaloid concentrations are highest in the early growth and decline gradually in the plants during the growing season, with the exception of the seed pods, which accumulate relatively high concentrations of alkaloids in the mature seeds.

Larkspurs are often heavily grazed by cattle during the summer on higher elevation rangelands, and, depending on the amount of plant consumed, the rate of consumption, and the concentration of toxic alkaloids in the plants, cattle may be fatally poisoned. Poisoned cattle show muscular weakness, trembling, rapid respiration, inability to stand, sternal recumbency (i.e., lying on their brisket), and eventually lateral recumbency (i.e., lying on their side) and death. Death is caused by respiratory paralysis, sometimes in combination with bloat. Animals may show all signs of larkspur toxicity, including muscular paralysis and recumbency, for many hours yet not be fatally poisoned. The severity and duration of clinical signs depends on the amount of larkspur consumed and the dose of alkaloids contained in the consumed plant material.

Management recommendations to reduce cattle losses to larkspurs are based primarily on when cattle are most likely to eat larkspurs, ${ }^{2}$ in conjunction with the concentration of toxic alkaloids in the plants. ${ }^{3}$ Many years of research on subalpine larkspur and duncecap larkspur concluded that cattle consume little or none of these two species of tall larkspur before the plants elongate flowering racemes (stalks with flowers along their length). ${ }^{2}$ Consumption by cattle typically begins at flowering and increases as the tall larkspur plants mature, with consumption by cattle peaking when tall larkspur is in the pod stage of growth in late summer.

Waxy larkspur in central Idaho and southwestern Montana (Fig. 1) occurs in somewhat different habitat compared to other tall larkspurs. It is found primarily in mountain meadows and sagebrush areas above 6,000 ft elevation, but these waxy larkspur-populated areas tend to be drier than those areas populated by duncecap larkspur. Duncecap larkspur typically grows in areas with deeper, moister soils, often with an abundance of other forbs and grasses. Previous chemical analysis by PPRL of waxy larkspur indicated that this larkspur species was highly toxic, containing a variety of toxic and less toxic alkaloids. However, there was no information available about cattle grazing of this tall larkspur species. Ranchers and extension personnel in central Idaho with whom we communicated had observed cattle deaths attributed to waxy larkspur during spring when the waxy larkspur plants were vegetative (Fig. 2) or in the bud stage of growth. These observations ran counter to previous PPRL research on the timing of tall larkspur consumption by cattle in areas dominated by subalpine and duncecap larkspurs.

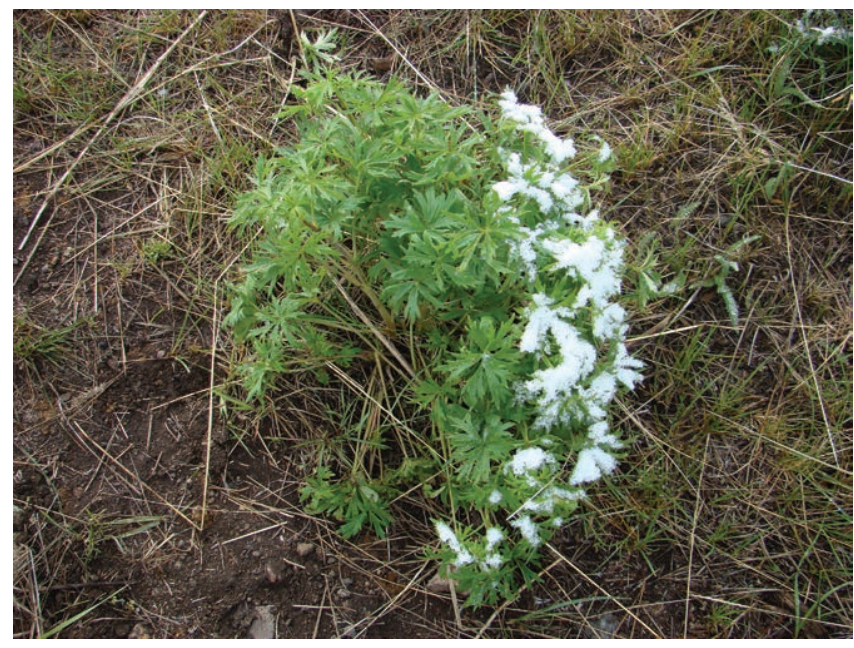

Figure 2. Waxy larkspur (Delphinium glaucescens) in the early stage of growth with a dusting of snow. Photo by J. Pfister.

\section{Grazing Study in Idaho}

To begin to answer the questions about when and how much waxy larkspur is eaten by cattle during spring, we conducted a small grazing study from 19 to 29 May 2012 in the Salmon River Mountains near Challis, Idaho. The study was located in Rattlesnake Gulch, on the West Fork of Morgan Creek, about 18 miles north of Challis (lat $44^{\circ} 42^{\prime} 18.05^{\prime \prime} \mathrm{N}$, long $114^{\circ} 18^{\prime} 16.29^{\prime \prime} \mathrm{W}$; elevation 7,250 feet). Precipitation in the area is about 8-12 inches annually, in the form of winter and spring moisture; winter precipitation during 2012 in the Challis area was lower than normal. A 3-acre pasture was fenced with electric fence in an area with patches of waxy larkspur in the vegetative and bud stage of growth. The pasture was dominated by Wyoming big sagebrush (Artemisia tridentata ssp. wyomingensis), tailcup lupine (Lupinus caudatus), and bluebunch wheatgrass (Pseudoroegneria spicata). The area was grazed with six Hereford steers that were naive to larkspur. The steers were gentle and habituated to the presence of observers before the study began. We quantified cattle diets using bite counts during all active grazing periods each day. The observer counted bites of waxy larkspur and all other forage by following each animal for 5-minute periods, then rotating through the entire group numerous times each day when they were actively grazing. In this way, about 1 hour of bite count data on each animal was collected each day of the study. Steers were placed in a corral at night at about 7:00 pm and released to graze at 6:30 am each morning. The vegetation was clipped to determine forage availability at the start of the study; the clipped material was saved for nutritional analysis (i.e., crude protein and fiber). Waxy larkspur plants were collected periodically for alkaloid and nutritional analysis.

\section{Larkspur Toxicity}

All of the forage at this study site was actively growing during the study. The spring forage was relatively abundant and had excellent nutritional characteristics (Table 1), with 
Table 1. Nutritional profile of available forage and waxy larkspur (Delphinium glaucescens) and the alkaloid concentration of waxy larkspur during a grazing study near Challis, Idaho, in spring 2012. All nutritional and alkaloid values are percentage of dry weight.

\begin{tabular}{|l|l|l|l|c|c|c|}
\hline Date & Forage & $\begin{array}{c}\text { NDF } \\
(\%)\end{array}$ & $\begin{array}{c}\text { Crude } \\
\text { protein (\%) }\end{array}$ & $\begin{array}{c}\text { Toxic alkaloids } \\
(\%)\end{array}$ & $\begin{array}{c}\text { Total alkaloids } \\
\text { (\%) }\end{array}$ & $\begin{array}{c}\text { Forage availability } \\
\text { (pounds/acre) }\end{array}$ \\
\hline 18 May & Grass & 60.6 & 15.1 & - & - & 410 \\
\hline & Forbs & 34.3 & 18.9 & - & - & 80 \\
\hline & Lupine & 38.2 & 19.9 & - & - & 100 \\
\hline & Larkspur & 22.8 & 20.2 & 2.33 & 3.01 & 15 \\
\hline 30 May & Larkspur & 27.2 & 17.3 & 2.19 & 2.60 & - \\
\hline
\end{tabular}

crude protein at $15 \%$ in the grasses. Waxy larkspur was also an excellent source of nutrition but was also very toxic, with toxic alkaloid concentrations above $2 \%$. The total alkaloid concentration exceeded 3\% and represents a mixture of very toxic and less toxic alkaloids. Even though some individual alkaloids are less toxic, recent research ${ }^{4}$ has shown that these less toxic alkaloids can exacerbate the negative effects of the highly toxic alkaloids. Larkspurs containing more than $0.6 \%$ toxic alkaloids are considered to be highly toxic. The alkaloid concentrations found in waxy larkspur at the study site present a high risk of poisoning for grazing livestock if they consume the plants.

\section{Larkspur Consumption by Cattle}

During the first few days on the study site, the steers ate very little waxy larkspur; however, on 23 May, one steer ate sufficient waxy larkspur (10\% of his total forage bites) that he showed visible signs of poisoning throughout the entire following day (Fig. 3). Similarly, on 25 and 26 May several steers ate sufficient larkspur that they were visibly poisoned on that day and the following day. Progression of the clinical signs followed the classical pattern of minor muscle tremors progressing to major tremors and then periodic collapse for 10-20 minutes. Within a few hours, affected steers would collapse, then lapse into sternal then lateral recumbency for 8 to 18 hours, depending on the severity of the poisoning episode. Even though the waxy larkspur was highly toxic, no animals were fatally poisoned, but two animals spent about 18 hours in lateral recumbency before recovering, an indication that they were very close to death.

Under these experimental circumstances, placing animals in the corral at night probably sufficiently interrupted and reduced their exposure to waxy larkspur such that no animals were fatally poisoned. Without this management intervention to allow the use of bite counts during daylight hours, it seems likely that two or more of the steers would have been fatally poisoned. When severely poisoned steers regained the ability to walk, they were visibly weak and depressed for about 48 hours after the poisoning episode; they also followed the classical pattern of not consuming waxy larkspur for several days after their recovery. This is essentially a temporary food aversion, but given sufficient opportunity, the aversion will disappear and cattle will return to eating waxy larkspur within a few days. Animals that collapsed were not given any drug therapy, even though injections with the drug neostigmine will quickly reverse the poisoning for several hours.

The average consumption of waxy larkspur by the entire group of steers is not a very useful indication of the likelihood of an animal getting poisoned because there is tremendous

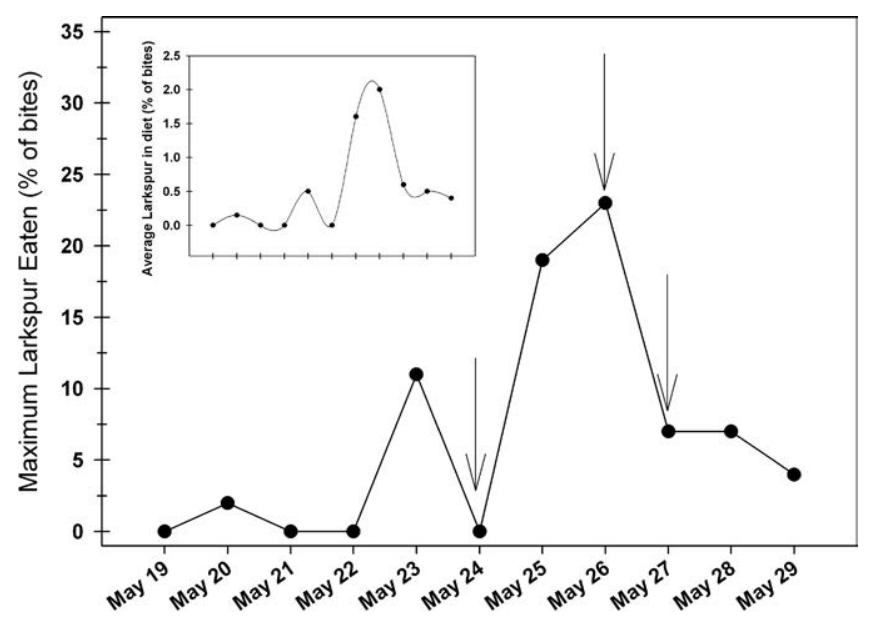

Figure 3. Maximum daily consumption of waxy larkspur (\% of bites) for steers grazing near Challis, Idaho, in 2012. Six steers grazed on this mountain pasture, and this figure represents the maximum daily larkspur consumption by any individual animal on that day. Arrows indicate that one or more steers were visibly intoxicated from eating waxy larkspur and were either sternally or laterally recumbent for part or all of that day. The inset graph shows the average daily consumption of waxy larkspur (\% of bites) for all the animals over the study period. 
variability among animals, and the main factor determining if animals will get poisoned is the maximum amount that they ingest during a grazing bout or an entire day. The waxy larkspur was not uniformly distributed throughout the pasture, and cattle appeared not to seek it out or avoid it during their grazing activity. Cattle consumption of waxy larkspur in this study was not due to a reduction in other available forage. Waxy larkspur is at least moderately palatable during spring, and cattle consume the plant when other forages are available. In situations where other nontoxic forages are lacking but there is abundant larkspur, catastrophic cattle losses may occur. ${ }^{5}$

\section{Conclusion}

In summary, our small grazing study demonstrated that management recommendations for other tall larkspur species such as subalpine and duncecap larkspurs do not apply to waxy larkspur. Unlike consumption patterns by cattle for these other two tall larkspur species, waxy larkspur is sufficiently palatable in spring to pose a serious threat to grazing cattle, and the risk of death losses is particularly high because of the very high concentrations of alkaloids in young waxy larkspur plants. The risk may also be accentuated for cattle grazing on rangelands with patchy, but locally abundant, populations of waxy larkspur because precipitation and resultant forage abundance may be lower compared to other mountain rangelands (called tall forb rangelands) where subalpine and duncecap larkspurs are the dominant tall larkspurs. Ranchers with tall larkspurs need to be keenly aware of which larkspur species is growing on their pastures and take precautions to limit cattle exposure to toxic larkspurs when cattle are most likely to consume the plants. The PPRL ${ }^{i}$ provides alkaloid analysis of larkspurs free of charge, and we encourage ranchers to use this service to gain an understanding of the relative toxicity of larkspur on their ranges.

'For more on the Poisonous Plant Research Laboratory, including contact information, see http://www.ars.usda.gov/npa/logan/pprl.

\section{Acknowledgment}

We thank Kermit Price and Scott Larsen for excellent technical assistance.

\section{References}

1. Pfister, J. A., D. R. Gardner, K. E. Panter, G. D. Manners, M. H. Ralphs, B. L. Stegelmeier, and T. K. Schoch. 1999. Larkspur (Delphinium spp.) poisoning in livestock. Journal of Natural Toxins 8:81-94.

2. Pfister, J. A., M. H. Ralphs, G. D. Manners, D. R. GardNER, K. W. Price, And L. F. James. 1997. Early season grazing by cattle of tall larkspur- (Delphinium spp.) infested rangeland. Journal of Range Management 50:391-398.

3. Pfister, J. A., M. H. Ralphs, D. R. Gardner, B. L. Stegelmeier, G. D. Manners, K. E. Panter, and S. T. Lee. 2002. Management of three toxic Delphinium species based on alkaloid concentrations. Biochemical Systematics and Ecology 30:129138.

4. Welch, K. D., B. T. Green, D. R. Gardner, D. Cook, J. A. Pfister, B. L. Stegelmeier, K. E. Panter, and T. Z. Davis. 2010. Influence of 7,8-methylenedioxylycoctonine-type alkaloids on the toxic effects associated with ingestion of tall larkspur (Delphinium spp.) in cattle. American Journal of Veterinary Research 71:487-492.

5. Pfister, J. A., D. R. Gardner, B. L. Stegelmeier, K. HackETt, AND G. Secrist. 2003. Catastrophic cattle loss to low larkspur (Delphinium nuttallianum) in Idaho. Veterinary and Human Toxicology 45:137-139.

Authors are Research Rangeland Management Specialist (Pfister, Jim.Pfister@ars.usda.gov), Research Plant Physiologist (Cook), and Research Chemist (Gardner), USDA-ARS Poisonous Plant Research Laboratory, Logan, UT 84341, USA; and Extension Educator, University of Idabo Extension Service, Custer County, Challis, ID 83226, USA (Baker). 